\title{
Assessment of the relationship between insulin resistance, atherogenic index of plasma and white blood cell count: A data mining study
}

\author{
Însülin direncinin plazma aterojenik indeks ve beyaz \\ küre sayısı ile ilişkisinin değerlendirilmesi: Bir veri \\ madenciliği çalışması
}

\author{
Halef Okan Doğan ${ }^{1}$, Güllhan Duman²
}

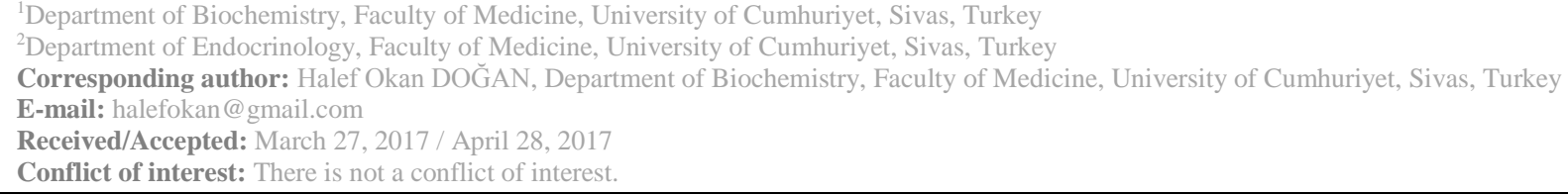

\section{SUMMARY}

Objective: The hyperinsulinemic-euglycemic clamp tests considered as a gold standard method for assessing the insulin sensitivity, whereas the application of this test in large groups is both difficult and not practical, therefore clinicians need calculating parameters to evaluate the insulin sensitivity. In the study we evaluated the prediction of insulin resistance (IR) by atherogenic index of plasma (AIP) and WBC count.

Method: We retrospectively reviewed the records of 139.934 individuals admitted to our hospital from March 2015 to March 2016. 474 individuals were enrolled in our study. Study population's records such as age, gender, white blood cell (WBC) count and the concentrations of overnight fasting blood glucose, triglyceride (TG), total cholesterol (TCHOL), HDL-C, low density lipoprotein cholesterol (LDL-C) and insulin were recorded from our hospital information system.

Results: The receiver operating characteristic curves (AUC) of AIP for predicting IR were 0.670 and 0.690 as measured by homeostatic model assessment-insulin resistance (HOMA-IR) and insulin sensitivity check index (QUICKI), respectively. The area under the curve (AUC) values for predicting IR with WBC count were 0.649 and 0.652 as measured by HOMA-IR and QUICKI, respectively.

Conlusions: Negative predictive values of AIP and WBC were found higher than positive predictive values as measured HOMA-IR. AIP and WBC may not serve as a predictor of IR lonely but these markers might be used as surrogate markers may contribute to excluding IR when used in combination with HOMA-IR and QUICKI.

Keywords : Atherogenic index of plasma, WBC count, Insulin resistance, Triglyceride, HDL

\section{ÖZET}

Amaç: Hiperglisemik öglisemik klemp testi insülin direncinin (ID) değerlendirilmesinde altın standart olarak kabul edilmektedir. Bununla birlikte bu testin geniş gruplarda uygulanması zor ve pratik değildir. Bu nedenle klinisyenler İD’nin değerlendirilmesinde hesaplamalı parametrelere ihtiyaç duymaktadır. $\mathrm{Bu}$ çalışmada insulin direncinin değerlendirilebilmesinde plazma aterojenik indeks (PAİ) ve beyaz küre (WBC) değerinin kullanılıp kullanılamayacağ tespit edilmeye çalışılmıştır.

Yöntem: Bu amaçla Mart 2015- 2016 y1lları arasında Cumhuriyet Üniversitesi Sağlık Hizmetleri Araştırma ve Uygulama Hastanesi'ne başvuran 138.934 kişinin bilgileri incelendi ve 474 kişi çalışmaya dahil edildi. Çalışma populasyonuna ait yaş, cinsiyet, WBC sayısı, açlık glukoz, trigliserid, total kolesterol, yüksek dansiteli lipoprotein kolesterol ve insulin düzeyi bilgileri hastane bilgi işlem sisteminden alındı.

Bulgular: İD’nin varlığının gösterilmesinde PAİ için elde edilen eğri altında kalan alan (AUC) değerleri homeostatic model assessment-insuline resistance (HOMA-IR) ve quantitative insulin sensitivity check index (QUICKI) için sırasıyla 0.670 ve 0.690 olarak tespit edildi. Bu değerler WBC için sırasıyla 0.649 ve 0.652 olarak bulundu. Ayrıca HOMA-IR değeri baz alındığında PAİ ve WBC'nin negatif prediktif değerinin pozitif prediktif değerinden daha yüksek olduğu görüldü. 
Sonuç: İnsulin direncinin tespitinde WBC ve AIP'in tek başına kullanılabilecek güvenilir bir belirteç olmadığı ancak bu parametrelerin HOMA-IR ve QUICKI ile birlikte insulin direncinin dışlanmasına katkı sağlayabileceği düşünülmektedir. Anahtar sözcükler: Plazma aterojenik indeks, WBC, insulin direnci, trigliserid, HDL

\section{INTRODUCTION}

The insulin resistance (IR) is increasingly recognized as a serious, worldwide public health problem and it is associated with central obesity, impaired glucose tolerance, diabetes mellitus, hypertension, dyslipidemia and cardiovascular disease $(\mathrm{CVD})^{1}$. The hyperinsulinemic-euglycemic clamp test was considered as a gold standard method for assessing the insulin sensitivity, whereas the application of this test in large groups is both difficult and not practical, therefore calculated parameters such as homeostatic model assessment-insulin resistance (HOMA-IR) and quantitative insulin sensitivity check index (QUICKI) has been emerged to evaluate the insulin sensitivity ${ }^{2,3}$. HOMA-IR has been widely used in the routine clinical assessment of patients with metabolic syndrome, however, because of the lack of standardization of insulin assay it has limited clinical utility ${ }^{4}$.

White blood cell (WBC) count is an indicator of the activation of inflammation and immune system ${ }^{5,6}$. Although, It has been proposed that the circulating WBC is one of the biomarkers for the predicting of cardiovascular risk and insulin resistant states ${ }^{5,7}$, the predictive ability of WBC count has not been fully explored for the prediction of IR and cardiovascular disease ${ }^{5,8,9}$. Hypertriglyceridemia and low high density lipoprotein cholesterol (HDLC) concentrations which are two important serum lipid abnormalities associated with $\mathrm{IR}^{10,11}$. The triglyceride (TG) to HDL-C ratio has been used as a predictor of $\mathrm{IR}^{12,13}$. However, some limitations have been reported on the use of TG/HDL-C ratio for evaluating $\mathrm{IR}^{14-16}$. Atherogenic index of plasma (AIP) which is the logarithmic transformation of the TG to HDL-C ratio (AIP = log TG/HDL-C) predicts the risk of atherosclerosis ${ }^{17}$. So far there are no data on the association between AIP and insulin sensitivity.

This study was set out with the aim of evaluating the prediction of IR by AIP and WBC count. We also aimed to evaluate the change of WBC counts according to different HDL-C and (TG) concentrations. In reviewing the literature, no data was found on the use of AIP and WBC count for assessing IR and evaluating the change of WBC counts in different HDL-C and TG concentrations.

\section{MATERIAL AND METHODS}

\section{Study subjects}

Study population were composed of 331 (69.8\%) female and $143(30.2 \%)$ male individuals. The average ages of individuals were 37.78 years (from 18 to 82 years). None of the participants had diabetes mellitus. Exclusion criteria in the study population included clinical suspicion of infections (body temperature out of the range between 36- 38 ${ }^{\circ} \mathrm{C}$, heart rate $>90$ rate/minute, respiratory rate > $20 /$ minute, WBC count $>12 \times 10^{3} \mathrm{mcL}$ or < $4 \times 10^{3} \mathrm{mcL}$ ), presence of liver diseases, kidney diseases, rheumatic disease, malignancy, pregnancy, cardiovascular disease, impaired thyroid functions, body mass index $\geq 25$ and taking lipid lowering drugs. Individual's records such as age, gender, WBC count and the concentrations of overnight fasting blood glucose, TG, total cholesterol (TCHOL), HDL-C, low density lipoprotein cholesterol (LDL-C) and insulin were obtained from Cumhuriyet University Hospital's laboratory information system. The protocol was approved by Cumhuriyet University Ethical Committee (2016-10/15).

\section{Study design}

In this study, we retrospectively reviewed the records of 139.934 individuals admitted to our hospital from March 2015 to March 2016. 474 individuals were enrolled to our study. To determine the affected parameters from IR study population was divided to four sub-groups according to the HOMA-IR and QUICKI index values. Threshold values for HOMA-IR and QUICKI were determined according to the studies made by Yamada et al. ${ }^{18}$, Salgado et al. ${ }^{19}$ and McAuley et al. ${ }^{20}$. We also investigated the use of WBC count and AIP for predicting the IR. Finally, we evaluated the change of WBC counts in the presence of different HDL-C and TG concentrations which are determined according to American Association of Clinical Endocrinologist's guidelines ${ }^{21}$.

\section{Biochemical analysis and determination of AIP, HOMA-IR and QUICKI}

Complete Blood Count analysis was performed using hematology system (Mindray BC6800, China). Fasting blood glucose, TG, TCHOL, HDL$\mathrm{C}$ and LDL-C concentrations were determined by enzymatic colorimetric method (Beckman Coulter AU5800, USA). Serum insulin concentrations 
were measured by using chemiluminescence immunoassay (Beckman Coulter Unicel DxI 800, USA). We calculated AIP, HOMA-IR and QUICKI values according to following formula; AIP: [log TG/HDL-C] (17), HOMA-IR: [fasting plasma glucose $(\mathrm{mg} / \mathrm{dL}) \mathrm{X}$ fasting serum insulin $(\mu \mathrm{IU} / \mathrm{mL}) / 405]^{22}$ and QUICKI: [1 / ( $\log ($ fasting insulin $\mu \mathrm{U} / \mathrm{mL})+\log ($ fasting glucose $\mathrm{mg} / \mathrm{dL})]^{23}$.

\section{Statistical analysis}

The Shapiro-Wilk's test was used and histogram and q-q plots were examined to assess the data normality. Accordingly Mann-Whitney U tests were used to compare the differences of continuous variables between binary groups. Receiver operating characteristic (ROC) curves were plotted for the WBC and AIP to detect the predictive performance of HOMA-IR and QUICKI. The area under curves and also, cut-offs were determined for each variable. Sensitivity, specificity, positive predictive rate, negative predictive rate, positive likelihood ratio, negative likelihood ratio and area under curve diagnostic measures were calculated. $R$ 3.2.2 softwares were used for all analyses. A $\mathrm{p}<0.05$ probability level was considered statistically significant.
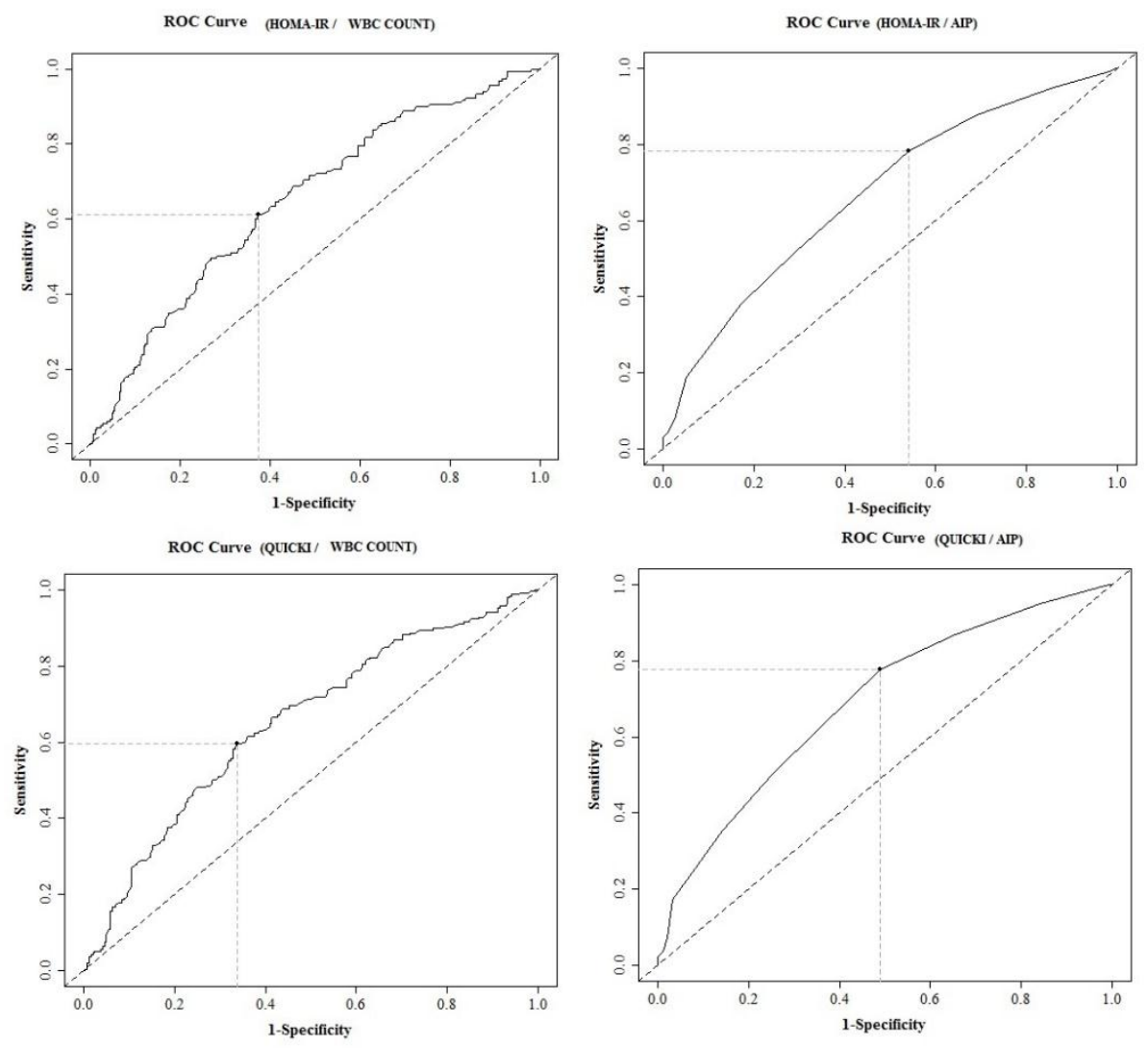

Figure 1. The area under the ROC curves for AIP and WBC count. A: represent the ROC curve for WBC count as measured by HOMA-IR, B: represent the ROC curve for AIP as measured by HOMA-IR, C: represent the ROC curve for WBC count as measured by QUICKI, D: represent the ROC curve for AIP as measured by QUIC 
Table 1. Comparison of the values of median fasting blood glucose, AIP, WBC count and serum lipids according to different HOMA-IR and QUICKI indices

\begin{tabular}{|c|c|c|c|}
\hline HOMA-IR & $<2.5(n: 293)$ & $\geq 2.5(n: 181)$ & $\mathrm{P}$ \\
\hline AIP & $0.3(0.1-0.5)$ & $0.5(0.3-0.7)$ & $<0.001$ \\
\hline WBC count $\left(10^{3} \mathrm{mcL}\right)$ & $6.39(5.5-7.5)$ & $7.3(6.2-8.3)$ & $<0.001$ \\
\hline $\mathrm{FBG}(\mathrm{mg} / \mathrm{dL})$ & $90.0(84.0-95.0)$ & $98.0(90.0-109.0)$ & $<0.001$ \\
\hline $\mathrm{TG}(\mathrm{mg} / \mathrm{dL})$ & $92.5(68.0-141.0)$ & $132.5(88.3-192.0)$ & $<0.001$ \\
\hline TCHOL (mg/dL) & $192.0(168.0-223.5)$ & $195.5(166.0-223.8)$ & $=0.712$ \\
\hline HDL-C (mg/dL) & $52.0(43.0-60.0)$ & $45.0(38.3-53.8)$ & $<0.001$ \\
\hline LDL-C (mg/dL) & $130.0(108.8-154.0)$ & $130.5(107.0-151.5)$ & $=0.859$ \\
\hline QUICKI & $<0.33(n: 237)$ & $\geq 0.33(n: 237)$ & \\
\hline AIP & $0.5(0.3-0.7)$ & $0.2(0.1-0.5)$ & $<0.001$ \\
\hline WBC count $\left(10^{3} \mathrm{mcL}\right)$ & $7.3(6.1-8.3)$ & $6.2(5.4-7.3)$ & $<0.001$ \\
\hline $\mathrm{FBG}(\mathrm{mg} / \mathrm{dL})$ & $97.0(89.5-104.5)$ & $89.0(84.0-94.0)$ & $<0.001$ \\
\hline $\mathrm{TG}(\mathrm{mg} / \mathrm{dL})$ & $128.0(88.0-189.5)$ & $87.0(66.0-136.0)$ & $<0.001$ \\
\hline TCHOL (mg/dL) & $192.0(167.0-223.0)$ & $193.0(168.0-225.0)$ & $=0.466$ \\
\hline $\mathrm{HDL}-\mathrm{C}(\mathrm{mg} / \mathrm{dL})$ & $45.0(38.5-54.0)$ & $53.0(44.0-61.0)$ & $<0.001$ \\
\hline LDL-C (mg/dL) & $130.0(108.5-149.0)$ & $131.0(108.0-155.0)$ & $=0.843$ \\
\hline
\end{tabular}

AIP: Atherogenic index of plasma, FBG: Fasting blood glucose, HDL-C: High density lipoprotein cholesterol, HOMAIR: Homeostatic model assessment-insulin resistance, LDL-C: Low density lipoprotein cholesterol, QUICKI: International normalization ratio WBC: white blood cell, TCHOL: Total cholesterol, TG: Triglyceride. Results are expressed as median $\left(25^{\text {th }}-75^{\text {th }}\right.$ percentile $)$ with $95 \%$ confidence intervals.

Table 2.Comparison of WBC values according to HDL-C and TG concentrations

\begin{tabular}{|c|c|c|c|}
\hline $\begin{array}{l}\text { HDL-C(mg/dL) } \\
\text { WBC count }\left(10^{3} \mathrm{mcL}\right)\end{array}$ & $\begin{array}{l}<\mathbf{6 0}(\boldsymbol{n}: \mathbf{3 7 8}) \\
6.95(5.90-8.02)\end{array}$ & $\begin{array}{l}\geq 60(\boldsymbol{n}: 96) \\
6.29(5.30-7.37)\end{array}$ & $\begin{array}{l}\mathrm{P} \\
<0.001 \\
\end{array}$ \\
\hline HDL-C (mg/dL) & $\leq 40(n: 103)$ & $>40(n: 371)$ & \\
\hline WBC count $\left(10^{3} \mathrm{mcL}\right)$ & $7.34(6.13-8.38)$ & $6.66(5.65-7.66)$ & $<0.001$ \\
\hline TG (mg/dL) & $<150(\mathrm{n}: 339)$ & $\geq 150(\mathrm{n}: 135)$ & \\
\hline WBC count $\left(10^{3} \mathrm{mcL}\right)$ & $6.70(5.65-7.70)$ & $6.99(6.10-8.18)$ & $\mathrm{p}=0.011$ \\
\hline
\end{tabular}

HDL-C:High density lipoproteins cholesterol, TG: Triglyceride, WBC: White blood cell. Results are expressed as median $\left(25^{\text {th }}-75^{\text {th }}\right.$ percentile) with $95 \%$ confidence intervals. 
Tablo 3. Statistical diagnostic measures of white blood cell count and atherogenic index of plasma for HOMA-IR and QUICKI

\begin{tabular}{|c|c|c|c|c|c|c|c|c|}
\hline \multirow{3}{*}{ Variable } & \multicolumn{6}{|c|}{ Diagnostic measures } & \multirow{2}{*}{\multicolumn{2}{|c|}{$\begin{array}{c}\text { Area under ROC } \\
\text { curve }\end{array}$}} \\
\hline & & & & & & & & \\
\hline & SEN(95\%CI) & SPE(95\%CI) & $\operatorname{PPR}(95 \% \mathrm{CI})$ & NPR(95\%CI) & $\mathrm{LR}+(95 \% \mathrm{CI})$ & LR-(95\%CI) & AUC & $p$ \\
\hline \multicolumn{9}{|l|}{ HOMA-IR } \\
\hline WBC (>6.94) & $0.61(0.54-0.68)$ & $0.63(0.57-0.68)$ & $0.50(0.44-0.58)$ & $0.72(0.66-0.77)$ & $1.63(1.35-1.97)$ & $0.62(0.51-0.76)$ & 0.649 & $<0.001$ \\
\hline $\operatorname{AIP}(>0.30)$ & $0.78(0.72-0.84)$ & $0.46(0.40-0.52)$ & $0.47(0.41-0.57)$ & $0.78(0.71-0.81)$ & $1.45(1.27-1.65)$ & $0.47(0.35-0.64)$ & 0.670 & $<0.001$ \\
\hline \multicolumn{9}{|l|}{ QUICKI } \\
\hline WBC (>6.94) & $0.60(0.53-0.66)$ & $0.66(0.60-0.72)$ & $0.64(0.57-0.70)$ & $0.62(0.56-0.68)$ & $1.76(1.43-2.17)$ & $0.61(0.51-0.73)$ & 0.652 & $<0.001$ \\
\hline $\operatorname{AIP}(>0.30)$ & $0.78(0.72-0.83)$ & $0.51(0.45-0.58)$ & $0.61(0.55-0.69)$ & $0.70(0.63-0.75)$ & $1.59(1.37-1.84)$ & $0.49(0.34-0.57)$ & 0.690 & $<0.001$ \\
\hline
\end{tabular}




\section{DISCUSSION}

This study aimed to develop a simple predictive model as a clinical tool for evaluation of IR. Therefore, we proposed the prediction of IR by AIP and WBC count. Whereas several studies investigated the use of TG/HDL-C ratio for predicting IR there is not any study on the use of AIP for evaluating the IR. The study made by McLaughlin et al. ${ }^{13}$ reported that TG/HDL-C ratio offer the most practical approach to identify IR. Kimmet al. ${ }^{24}$ indicated that TG/HDL-C was a consistent indicator of IR in subjects without metabolic syndrome. It was also reported that TG/HDL-C was not a reliable predictor for IR because of racial differences ${ }^{14,15}$. The current study found positive correlation between AIP and HOMA-IR. Additionally we found negative correlation between AIP and QUICKI. In this study the receiver operating characteristics of AIP for predicting IR were 0.670 and 0.690 as measured by HOMA-IR and QUICKI, respectively. In our study threshold value of AIP for determining IR was determined as 0.3 . Additionally negative and positive predictive values of this threshold value were 0.78 and 0.47 , respectively. In the studies made by Kannel et al. ${ }^{25}$ and Kim-Dorner et al. ${ }^{14}$ the AUC of TG/HDL-C were found to be 0.77 and 0.75. Our AUC values were found lower than the other studies. We think that AIP is not a reliable marker that can be used alone to detect the IR. However the negative predictive value of this marker was found higher than positive predictive value. Therefore we think that AIP might be useful in excluding IR when used in combination with HOMA-IR and QUICKI.

White blood cell count has been shown as a risk factor for cardiovascular disease. Decreased insulin sensitivity has been suggested as the link between WBC count and cardiovascular disease ${ }^{26}$. Several studies reported that the positive correlation between WBC count and $\mathrm{IR}^{5,27}$. Whereas there is not any study on the use of WBC count for predicting IR. Chaoet al. ${ }^{28}$ found that the threshold value of WBC count for predicting the future metabolic syndrome was $5 \times 10^{3} \mathrm{mcL}$. Oda et al. ${ }^{29}$ reported that the WBC count threshold values were $5 \times 10^{3} \mathrm{mcL}$ and $5.63 \times 10^{3} \mathrm{mcL}$ for women and men to predict the metabolic syndrome, respectively. Twig et al. ${ }^{27}$ reported that WBC count above $6.9 \mathrm{x}$ $10^{3} \mathrm{mcL}$ had an independent $52 \%$ increase in diabetes risk compared with the lowest quintile. We found that individuals whose WBC count greater than $6.93 \times 10^{3} \mathrm{mcL}$ are more insulin resistant than the others having WBC count less than $6.93 \times 10^{3} \mathrm{mcL}$. Positive and negative predictive value of this threshold values were found as 0.50 and 0.72 . The threshold value proposed by Twig et $\mathrm{al}^{27}$ were similar to ours value. In the present study the AUC values for predicting IR with WBC count were 0.649 and 0.652 as measured by HOMA-IR and QUICKI, respectively. We think that as in the AIP, WBC count is not a reliable marker that can be used alone in evaluating IR due to low AUC values. Whereas WBC count might be useful in excluding IR when used in combination with HOMA-IR and QUICKI in non-obese and non-diabetic individuals.

Insulin resistance is a major risk factor for diabetes, metabolic syndrome and cardiovascular disease ${ }^{30}$. Dyslipidemia associated with IR play an important role in accelerated atherosclerotic cardiovascular disease $^{25}$. IR significantly impacts on the concentrations of TG and HDL-C. It has been reported that high concentrations of TG, low concentrations of HDL-C and unchanged concentrations of TCHOL and LDL-C in case of $\mathrm{IR}^{10,12,31-36}$. Similar to these findings we have found higher TG concentrations, lower HDL-C concentrations, unchanged LDL-C and TCHOL concentrations in persons who have the values of HOMA-IR $\geq 2.5$ and OUICKI $<0.33$. Our findings match those observed in earlier studies. Isolated low HDL-C concentrations are seen rarely and this situation is generally associated with genetic disorders ${ }^{37}$. Many investigators have postulated that hypertriglyceridemia combined with action of hepatic lipase forces in the reduction of HDL-C in IR state ${ }^{31,37}$. Another potential mechanism for the reduced HDL-C concentrations in hypertriglyceridemic insulin resistant state is the affected cholesterol transfer metabolism between TG rich lipoprotein and HDL-C rich lipoproteins $\mathrm{s}^{38,39}$. In this study we found statistically significant difference in terms of WBC count between individuals grouped according to different TG and HDL-C concentrations. Although the low $r$ value we also found positive correlation between the values of WBC count, AIP, HOMA-IR, TG and insulin and also we found negative correlation between HDL-C, QUICKI. Talukdar et al. ${ }^{40}$ discovered that an enzyme secreted by neutrophils called neutrophil elastase impairs insulin signaling and boosts IR. Taken together, our results suggest that the increase of WBC count within the reference range affects the concentrations of $\mathrm{TG}$ and HDL-C by disrupting the cellular insulin response in non-diabetic and non-obese persons.

The main limitation of this study is that the lack of information on smoking, alcohol intake, regular physical exercise, and family history of diabetes status of the study population. In addition, the relatively homogeneous ethnic group and 
environment to which participants in our study were exposed might reduce the effect of unknown confounders.

\section{CONCLUSION}

AIP and WBC may not serve as a predictor of IR lonely but these markers might be used as surrogate markers for excluding IR when used in combination with HOMA-IR and QUICKI. The changes in WBC count within normal ranges are associated with the concentrations of HDL-C and TG in nondiabetic and normal weight individuals. Future research is warranted to assess the use of AIP and WBC count for predicting IR in a larger population.

\section{REFERENCES}

1. Steinberger J, Daniels SR; American Heart Association Atherosclerosis, Hypertension, and Obesity in the Young Committee (Council on Cardiovascular Disease in the Young); American Heart Association Diabetes Committee (Council on Nutrition, Physical Activity, and Metabolism). Obesity, insulin resistance, diabetes, and cardiovascular risk in children: an American Heart Association scientific statement from the Atherosclerosis, Hypertension, and Obesity in the Young Committee (Council on Cardiovascular Disease in the Young) and the Diabetes Committee (Council on Nutrition, Physical Activity, and Metabolism). Circulation 2003; 18: 1448-53.

2. Tam CS, Xie W, Johnson WD, Cefalu WT, Redman LM, Ravussin E. Defining insulin resistance from hyperinsulinemic-euglycemic clamps. Diabetes Care 2012; 35: 1605-10.

3. Katz A, Nambi SS, Mather K, Baron AD, Follmann DA, Sullivan G, Quon MJ. Quantitative insulin sensitivity check index: a simple, accurate method for assessing insulin sensitivity in humans. J Clin Endocrinol Metab 2000; 85: 2402-10.

4. Miller WG, Thienpont LM, Van Uytfanghe K, Clark PM, Lindstedt P, Nilsson G, Steffes MW; Insulin Standardization Work Group. Toward standardization of insulin immunoassays. Clin Chem 2009; 55: 1011-8.

5. Vozarova B, Weyer C, Lindsay RS, Pratley RE, Bogardus C, Tataranni PA. High white blood cell count is associated with a worsening of insulin sensitivity and predicts the development of type 2 diabetes. Diabetes 2002; 51: 455-61.

6. Nakanishi N, Yoshida H, Matsuo Y, Suzuki $\mathrm{K}$, Tatara K. White blood-cell count and the risk of impaired fasting glucose or Type II diabetes in middle-aged Japanese men. Diabetologia 2002; 45: 42-8.

7. Yamamoto E, Sugiyama S, Hirata Y, Tokitsu T, Tabata N, Fujisue K, Sugamura K, Sakamoto K,
Tsujita K, Matsumura T, Kaikita K, Hokimoto S. Prognostic significance of circulating leukocyte subtype counts in patients with coronary artery disease. Atherosclerosis. 2016; 255: 210-6.

8. Pearson TA, Mensah GA, Alexander RW, Anderson JL, Cannon RO, Criqui M, Fadl YY, Fortmann SP, Hong Y, Myers GL, Rifai N, Smith SC Jr, Taubert K, Tracy RP, Vinicor F. Centers for Disease Control and Prevention; American Heart Association. Markers of inflammation and cardiovascular disease: application to clinical and public health practice: A statement for health care professionals from the Centers for Disease Control and Prevention and the American Heart Association. Circulation 2003; 28: 499-511.

9. Chen LK, Lin MH, Chen ZJ, Hwang SJ, Chiou ST. Association of insulin resistance and hematologic parameters: Study of a middle-aged and elderly Chinese population in Taiwan. J Chin Med Assoc 2006; 69: 248-53.

10. Lewis GF, Steiner G. Hypertriglyceridemia and its metabolic consequences as a risk factor for atherosclerotic cardiovascular disease in noninsulin-dependent diabetes mellitus. Diabetes Metab Rev 1996; 12: 37-56.

11. Brinck JW, Thomas A, Lauer E, Jornayvaz FR, Brulhart-Meynet MC, Prost JC, Pataky Z, Löfgren P, Hoffstedt J, Eriksson M, Pramfalk C, Morel S, Kwak BR, van Eck M, James RW, Frias MA. Diabetes Mellitus Is Associated With Reduced High-Density Lipoprotein Sphingosine1-Phosphate Content and Impaired High-Density Lipoprotein Cardiac Cell Protection. Arterioscler Thromb Vasc Biol 2016; 36: 817-24.

12. McLaughlin T, Reaven G, Abbasi F, Lamendola C, Saad M, Waters D, Simon J, Krauss RM: Is there a simple way to identify insulinresistant individuals at increased risk of cardiovascular disease? Am J Cardiol 2005, 96: 399-404.

13. McLaughlin T, Abbasi F, Cheal K, Chu J, Lamendola C, Reaven G. Use of metabolic markers to identify overweight individuals who are insulin resistant. Ann Intern Med 2003; 139: 802-9.

14. Kim-Dorner SJ, Deuster PA, Zeno SA, Remaley AT, Poth M: Should triglycerides and the triglycerides to high-density lipoprotein cholesterol ratio be used as surrogates for insulin resistance? Metabolism 2010; 59: 299-304.

15. Mostafa SA, Davies MJ, Morris DH, Yates T, Srinivasan BT, Webb D, Brady E, Khunti K. The association of the triglyceride-to-HDL cholesterol ratio with insulin resistance in White European and South Asian men and women. PLoS One 2012; 7 : e50931.

16. Deng QW, Wang H, Sun CZ, Xing FL, Zhang HQ, Zuo L, Gu ZT, Yan FL. Triglyceride to high- 
density lipoprotein cholesterol ratio predicts worse outcomes after acute ischaemic stroke. Eur J Neurol 2017; 24: 283-91.

17. Dobiasova M. Atherogenic index of plasma [log(triglycerides/HDL-cholesterol)]: theoretical and practical implications. Clin Chem 2004; 50: 1113-5.

18. Yamada C, Mitsuhashi T, Hiratsuka N, Inabe F, Araida N, Takahashi E. Optimal reference interval for homeostasis model assessment of insulin resistance in a Japanese population. $\mathbf{J}$ Diabetes Investig 2011; 2: 373-7

19. Salgado AL, CarvalhoLd, Oliveira AC, Santos VN, Vieira JG, Parise ER. Insulin resistance index (HOMA-IR) in the differentiation of patients with non-alcoholic fatty liver disease and healthy individuals. Arq Gastroenterol 2010; 47: 165-9.

20. McAuley KA, Williams SM, Mann JI, Walker RJ, Ledwis-Barned NJ, Temple LA, Duncan AS. Diagnosing insulin resistance in the general population. Diabetes Care 2001; 24: 460-4.

21. Jellinger PS, Mehta AE, Handelsman Y, Shepherd MD. American association of clinical endocrinologist's guidelines for management of dyslipidemia and prevention of atherosclerosis. Endocrine Practice 2012; 18(sup 1): 3-78.

22. Matthews DR, Hosker JP, Rudenski AS, Naylor BA, Treacher DF, Turner RC. Homeostasis model assessment: insulin resistance and $\beta$-cell function from fasting plasma glucose and insulin concentrations in man. Diabetologia 1985; 28: 4129.

23. Katz A, Nambi SS, Mather K, Baron AD, Follmann DA, Sullivan G, Quon MJ. Quantitative insulin sensitivity check index: a simple, accurate method for assessing insulin sensitivity in humans. J Clin Endocrinol Metab 2000; 85: 2402-10.

24. Kimm H, Lee SW, Lee HS, Shim KW, Cho CY, Yun JE, Jee SH. Associations between lipid measures and metabolic syndrome, insulin resistance and adiponectin. Usefulness of lipid ratios in Korean men and women. Circ J 2010; 74: 931-7.

25. Kannel WB, Vasan RS, Keyes MJ, Sullivan LM, Robins SJ. Usefulness of the triglyceridehigh-density lipoprotein versus the cholesterolhigh-density lipoprotein ratio for predicting insulin resistance and cardiometabolic risk (from the Framingham Offspring Cohort). Am J Cardiol 2008; 101: 497-501.

26. Piedrola G, Novo E, Escobar F, Garcia-Robles $\mathrm{R}$. White blood cell count and insulin resistance in patients with coronary artery disease. Ann Endocrinol (Paris) 2001; 62: 7-10.

27. Twig G, Afek A, Shamiss A, Derazne E, Tzur D, Gordon B, Tirosh A. White blood cells count and incidence of type 2 diabetes in young men. Diabetes Care 2013; 36: 276-82.

28. Chao TT, Hsieh CH, Lin JD, Wu CZ, Hsu $\mathrm{CH}$, Pei D, Chen YL, Liang YJ, Chang JB. Use of white blood cell counts to predict metabolic syndrome in the elderly: a 4 year longitudinal study. Aging Male 2014; 17: 230-7.

29. Oda E, Kawai R. Comparison between highsensitivity C-reactive protein (hs-CRP) and white blood cell count (WBC) as an inflammatory component of metabolic syndrome in Japanese. Intern Med 2010; 49: 117-24.

30. Reaven GM. Banting lecture 1988. Role of insulin resistance in human disease. Diabetes 1988; 37: 1595-607.

31. Lamarche B, Lewis GF. Atherosclerosis prevention for the next decade: risk assessment beyond low density lipoprotein cholesterol. Can J Cardiol 1998; 14: 841-51.

32. Ginsberg HN. Lipoprotein physiology in nondiabetic and diabetic states. Relationship to atherogenesis. Diabetes Care 1991; 14: 839-55.

33. Taskinen MR. Diabetic dyslipidaemia: from basic research to clinical practice. Diabetologia 2003; 46: 733-49.

34. Howard BV. Lipoprotein metabolism in diabetes mellitus. J Lipid Res 1987; 28: 613-28

35. Temelkova-Kurktschiev T, Hanefeld M. The lipid triad in type 2 diabetes-prevalence and relevance of hypertriglyceridaemia/low highdensity lipoprotein syndrome in type 2 diabetes. Exp Clin Endocrinol Diabetes 2004; 112: 75-9.

36. Karhapaa P, Voutilainen E, Kovanen PT, Laakso M. Insulin resistance in familial and nonfamilial hypercholesterolemia. Arterioscler Thromb 1993; 13: 41-7.

37. Rashid, S, Uffelman, K, Lewis, GF. The mechanism of HDL lowering in hypertriglyceridemic, insulin resistant states. J Diabetes Complications 2002; 16: 24-28.

38. Mann CJ, Yen FT, Grant AM, et al. Mechanism of plasma cholesteryl ester transfer in hypertriglyceridemia. J Clin Invest 1991; 88: 205966.

39. Föger B, Ritsch A, Doblinger A, Wessels H, Patsch JR. Relationship of plasma cholesteryl ester transfer protein to HDL cholesterol. Studies in normotriglyceridemia and moderate hypertriglyceridemia. Arterioscler Thromb Vasc Biol 1996; 16: 1430-6.

40. Talukdar S, Oh DY, Bandyopadhyay G, Li D, $\mathrm{Xu} \mathrm{J}$, McNelis J, Lu M, Li P, Yan Q, Zhu Y, Ofrecio J, Lin M, Brenner MB, Olefsky JM. Neutrophils mediate insülin resistance in mice fed a high-fat diet through secreted elastase. Nat Med 2012; 18: 1407-12. 